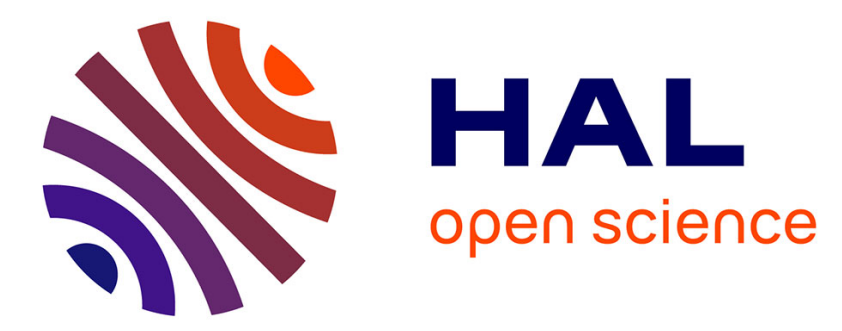

\title{
Coping with the Tiny: Measures, Computations, and Reasoning with Small Amounts in Jean des Murs's Quadrivial Works
}

\author{
Matthieu Husson
}

\section{To cite this version:}

Matthieu Husson. Coping with the Tiny: Measures, Computations, and Reasoning with Small Amounts in Jean des Murs's Quadrivial Works. Erudition and the Republic of Letters, 2019, 4 (1), pp.146-165. 10.1163/24055069-00401007 . hal-02551998

\section{HAL Id: hal-02551998 \\ https://hal.science/hal-02551998}

Submitted on 23 Apr 2020

HAL is a multi-disciplinary open access archive for the deposit and dissemination of scientific research documents, whether they are published or not. The documents may come from teaching and research institutions in France or abroad, or from public or private research centers.
L'archive ouverte pluridisciplinaire HAL, est destinée au dépôt et à la diffusion de documents scientifiques de niveau recherche, publiés ou non, émanant des établissements d'enseignement et de recherche français ou étrangers, des laboratoires publics ou privés. 
Coping with the tiny: measures, computations, and reasoning with small amounts in Jean des

Murs's quadrivial works

Matthieu Husson*

Observatoire de Paris, Université PSL, CNRS, Sorbonne Université, LNE

\begin{abstract}
Jean des Murs's contributions in geometry and arithmetic are numerous, diverse, and complex. They cannot be done justice in the context of a single essay. Moreover, some depth of analysis is required in order to address general questions of Jean des Murs's working habits and relations to his sources. Under these circumstances, I have chosen to focus on a specific question: in how far do Jean des Murs's mathematical works reflect a persistent effort throughout his career to address the various issues related to small amounts? Focusing on this particularly significant issue will give me the opportunity to cover a representative sample of Jean des Murs's quadrivial works from a specific perspective and thus complement the intellectual portrait presented in this volume.
\end{abstract}

\title{
Keywords
}

Jean des Murs; music theory; astronomy; small amounts; fractions; large numbers; incommensurability

\footnotetext{
* This research was supported by the European Research Council (ERC) under the European Union's Horizon 2020 research and innovation program (CoG, Grant agreement $n .723085)$, in the context of the project ALFA, Shaping a European scientific scene: Alfonsine astronomy (PI Matthieu Husson, 2017-2022). I am grateful for the many insights on this research topic provided by the participants of the international conference "Jean des Murs and His Quadrivial Works" (Oxford, All Souls College, June 2017) as well as to the anonymous referee, Philipp Nothaft, and Karen Desmond for their numerous suggestions on earlier drafts of this article.
} 


\section{Introduction}

This paper aims at complementing the cross-disciplinary intellectual portrait of Jean des Murs presented in this special issue from the particular perspective of his arithmetical and geometrical works. If looked at from this angle, the general question immediately implies new ones: what are the connections between Jean's arithmetical or geometrical works and those in the other field of the quadrivium? What is the importance of these mathematical works in the global intellectual picture of Jean des Murs as a quadrivial author of the fourteenth century?

Jean des Murs's contributions to geometry and arithmetic are distributed across his intellectual career. They cover most of the known topics of theses disciplines, sometimes with original approaches, and present diverse formats and styles, from short notes to encyclopaedic works. ${ }^{1}$ This complexity cannot be fairly dealt with in the context of a single essay. Moreover, some depth of analysis is required in order to address the general questions of Jean des Murs's working habits and relations to his sources. Under these circumstances, I have chosen to focus on a specific question: in what way do Jean des Murs's mathematical works reflect a careerspanning effort to address the various issues related to small amounts? Small amounts require specific mathematical techniques in order to express them, to measure them, and to operate with them. These techniques can be studied in Jean des Murs's extant writings. The issues related to small amounts are often connected to the problem of incommensurability in Jean de Murs's works. They are central to the longue durée of the historical development of mathematical disciplines. Moreover, the connection of this mathematical node of problems with the empirical question of measurement and observation, which for Jean des Murs was embedded in music and astronomy, can also be explored in his writings. This allows us to gain an understanding of the relations between Jean des Murs's works in arithmetic or geometry and those in music or astronomy.

In order to follow this thread in Jean des Murs's oeuvre I will explore successively the musical and astronomical context. In each context, I will first show how the issue of small amounts appears and then explore the kinds of mathematical answers Jean des Murs is able to bring to bear on the issue. Some interesting differences between the musical and astronomical contexts will emerge from this. Beyond them, I hope to cast light on some deep similarities

\footnotetext{
${ }^{1}$ Jean de Murs mathematical works include: Figura inveniendi sinus in kargada (see Maximilian Curtze, 'Urkunden zur Geschichte der Trigonometrie im christlichen Mittelalter', Bibliotheca mathematica, 3rd ser., 1 (1900), 321-416, at 413-16); the Arbor Boecii (copies include MSS Erfurt, Universitäts- und Forschungsbibliothek, Amplon. F. 377, fol. 35v-36r; Paris, Bibliothèque nationale de France, lat. 16621, fols. 62v-64r); Tabula tabularum (copies include MSS Paris, Bibliothèque nationale de France, lat. 7401, pp. 115124; Erfurt, Universitäts- und Forschungsbibliothek, Amplon. F. 377, fols. 35v-36r, 37r-38r; London, British Library, Add. 24070, fols. 64r-67r); De arithmetica (H. L. L. Busard, 'Die Arithmetica speculativa des Johannes des Muris', Scientiarum historia 13 (1971), 103-32; but see also Gilles Rico, 'Music in the Arts Faculty of Paris in the Thirteenth and Early Fourteenth Centuries' (D.Phil. diss., Oxford University, 2005), 67 n. 179, who doubts the attribution to Jean des Murs); Quadripartitum numerorum (ed. Ghislaine l'Huillier, Le Quadripartitum numerorum de Jean de Murs (Geneva, 1990)); De arte mensurandi (ed. H. L. L. Busard, Johannes de Muris, 'De Arte Mensurandi': A Geometrical Handbook of the Fourteenth Century (Stuttgart, 1998)). Of his musical and astronomical works, this paper will consider the De musica, the Notitia artis musicae, and the Expositio intentionis regis alfonsii circa tabulas ejus. For editions see Elżbieta Witkowska-Zaremba, Musica Muris i nurt spekulatywny w muzykografii średniowiecznej (Warsaw, 1992); Ulrich Michels, Johannis de Muris artis musicae et Compendium musicae practicae ([Dallas, TX]: American Institute of Musicology, 1972); Christian Meyer, Jean des Murs: écrits sur la musique (Paris, 2000), 57-111, 133-193; Emmanuel Poulle, 'Jean de Murs et les Tables Alphonsines', Archives d'histoire doctrinale et littéraire du Moyen Âge 47 (1980), 241-71.
} 
between the two situations, which attest to the intellectual coherence between quadrivial sciences as attested by Jean des Murs's works.

\section{Musical context}

The main locus for the appearance of issues related to small amounts in a musical context is the theory of micro-intervals (i.e., those that divide the tone: the major semitone, the minor semitone and the comma, mainly). Jean des Murs's discussion of these issues, although less developed than those found later in the monumental Speculum musicae of Jacques de Ispania, ${ }^{2}$ is nonetheless quite thorough. In a way typical of his working habits, Jean des Murs addresses the question at least two times in two different works. A minimal treatment is provided in the Notitia artis musicae. One here only finds a demonstration that the tone cannot be divided into two exact semitones. ${ }^{3}$ This shows Jean des Murs's early interest in the topic. Later, in the Musica speculativa, Jean des Murs gives a more extensive treatment of micro-intervals with 10 conclusions demonstrated and 13 more proposed with no demonstration. ${ }^{4}$ From these I have chosen his proof that six tones are greater than an octave as an example of how small amounts appear in a musical context for Jean des Murs. This property and its proof is one of the ways to define the comma. The piece of reasoning from the Musica speculativa presented here is by no means an original contribution of Jean des Murs. It is rather a standard element of musical theory and is for this reason a good point from where to start the inquiry.

In order to understand this reasoning one needs to recall the definition of the octave and the tone as proportions in musical theory. An octave is defined as the double proportion, i.e., the proportion 2:1. A tone is defined as a sesquioctave proportion, i.e., the proportion 9:8. On this basis Jean des Murs proves that six tones are greater than an octave in simple way. Starting from a well-chosen number as a base, 262144 (i.e., $8^{6}$ ), he construct six continuous tones and obtains the number 531441 (i.e., $\left.8^{6 *}(9 / 8)^{6}=9^{6}\right)$. Then, coming back to the base number, he constructs an octave and obtains the number 524288 (i.e., $2^{*} 8^{6}$ ). A simple comparison of these last two numbers shows that the first (i.e., 6 tones) is greater by 7153 than the second (i.e., the octave). The proportion between the numbers 524288 and 531441 is then defined as a comma. ${ }^{5}$

Let thus six tones in continuous proportions be found according to the rule presented before in the seventh [conclusion], starting from the sixth power of eight, as shown in the figure below. If, to this number, its eighth part is added, the first tone is found. To this, its eighth part is added, the second tone appears. To this, its eighth part is added again, the third tone is produced, and so on for the others until the sixth; and there are six successive continuous tones. Then, if the first is added to itself, a number forming an octave will be made according to the figure of circles. And

\footnotetext{
${ }^{2}$ Jacobi Leodiensis Speculum musicae, ed. Roger Bragard (Rome, 1955-73). Jacobus de Ispania was formerly known as Leodiensis. However, several recent works questioned this name. See Karen Desmond, 'New Light on Jacobus, Author of Speculum musicae', Plainsong and Medieval Music 9 (2000), 19-40, at 35; Margaret Bent, Magister Jacobus de Ispania, Author of the Speculum musicae (Farnham, 2015); R. C. Wegman, 'Jacobus de Ispania and Liège', Journal of the Alamire Foundation 8 (2016), 253-74. For a study of Jacobus de Ispania arithmetical methods see John N. Crossley, 'The Writings of Boethius and the cogitations of Jacobus de Ispania on musical proportions', Early Music History 36 (2017), 1-30.

${ }^{3}$ Jean des Murs, Notitia, I.4, Meyer, Jean de Murs, 70-1.

${ }^{4}$ Jean des Murs, De musica, I.conclusion 6-15, Meyer, Jean de Murs, 150-67.

${ }^{5}$ The parallel in Boethius, De institione musica II.30, ed. G. Friedlein (Leipzig, 1867), 266-67.
} 
this number is 524288 , which is smaller than the number forming six tones, that is 531441 . Their difference is 7153 , by which six tones are greater than an octave, which was the query. ${ }^{6}$

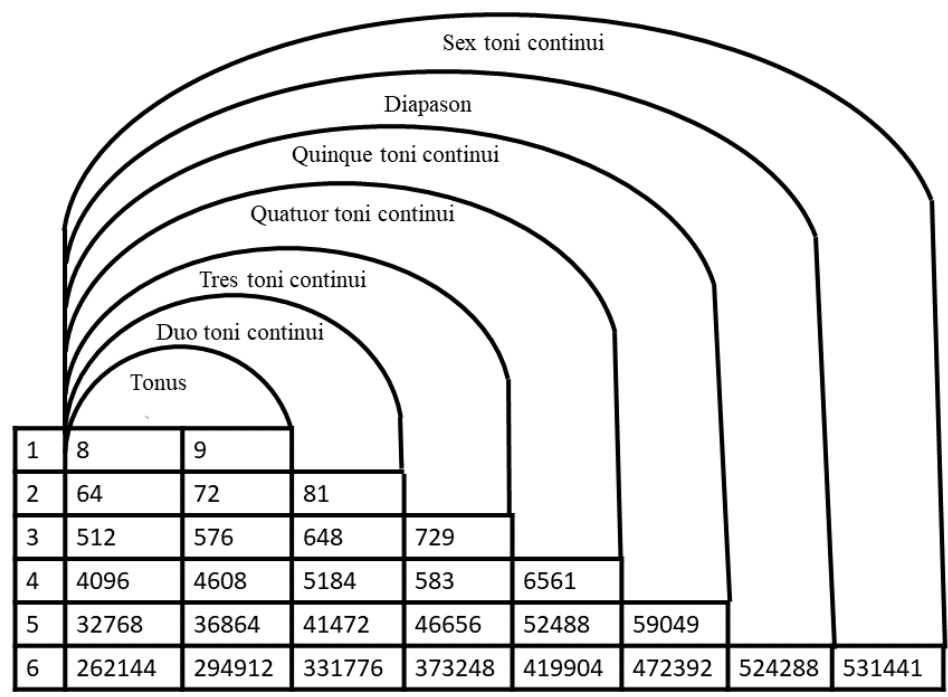

It is important to note here that while an additive vocabulary is used when speaking of musical intervals (subtract an octave from six tones, add one tone to the other) the actual arithmetical operation involved in the building of proportions with integers is multiplicative. The diagram of the proposition shows the relations between the level of the proportions or musical interval with an additive vocabulary and the level of numbers with a multiplicative vocabulary. ${ }^{7}$

The deductive structure of the text with reference to the conclusions presented before is remarkable. This structure is not accidental and Jean des Murs constructed the whole Musica speculativa in a very cautious way in this respect following the rules of Aristotle's Organon, which he exposes in his introduction to the text. This type of exposition is related to the Parisian university context in which the Musica speculativa was first conceived. ${ }^{8}$ For Jean des Murs, the whole deductive construction of musical theory relies on an empirical basis that the student is encouraged to explore using the monochord as a measuring instrument. In this respect it is important for my purpose to remember that the comma stands at the theoretical limit of sensible perception.

For in cases where the learner does not believe, one has to allow him to take recourse to experience, which will render him certain, with all ambiguity removed. ${ }^{9}$

\footnotetext{
${ }^{6}$ Jean des Murs, Musica, I.13, Meyer, Jean de Murs, 160: 'Sint ergo sex toni continue proportionales inventi secundum regulam ante dictam in septima, incipiendo a sexto octuplo, sicut hic in subscripta figura habetur; super quem si octava pars sui addatur, exibit primus tonus. Cui octava pars sui adiungatur, surget secundus tonus. Cui octava pars sui iterum adiungatur, tertius producetur et ita de aliis usque ad sextum; et erunt sex toni conitnui sucessive. Modo si supra primum ipsemet addatur, exibit numerus faciens diapason per figuram circulorum. Et est iste 524288, qui minor est eo numero, qui sextum faciebat tonum, scilicet 531441. Quorum differentia est 7153, in qua sex toni sunt maiores diapason, quod quaerebam.'

${ }^{7}$ See Elżbieta Witkowska-Zaremba's contribution in this issue for a more general reflection on the diagram in Jean des Murs's musical works.

${ }^{8}$ Meyer, Jean de Murs, 17-29.

${ }^{9}$ Meyer, Jean de Murs, 142: 'Oportet enim concedere, eum qui discit, quod si non credat, ad experientiam recurrat, et certus reddetur omni ambiguitate remota'.
} 
The basic structure of the argument is important. The small amount is produced by a comparison, in mathematical terms by a subtraction, of two very close quantities. Thus the reasoning has two steps. In a preparatory stage it produces the quantities to be compared. In the subsequent stage, it puts these quantities into a mathematical relation that allows their comparison and the definition of pertinent small quantities to quantify the comparison.

It is important to note the properties of the numbers used in this reasoning. In order to be able to compare small quantities, here the difference between six tones and an octave, one needs numbers with 'many' digits. Six digits are necessary to express a comma. If one considers that in micro-interval theory the comma is the start of an inquiry that will count more than eight and less than nine commas in a tone,${ }^{10}$ we see that the number of digits to manipulate is an important concern. Jean de Murs develops different strategies to address this specific issue. One of them is the use of fractions. For instance, in the proof that follows directly upon the one presented here, the difference between the fourth and the fifth is considered. In this proposition Jean des Murs compares numbers such as $43690 \frac{2}{3}, 44286 \frac{3}{4}$, and $59049 .{ }^{11}$ Strictly considered this use of fractions is not orthodox, as musical theory should be expressed only with integers. Jean de Murs is not the first musical theorist to confront this issue. Boethius also had to adapt his methods, for instance by approximating geometrical means with arithmetical ones. In fact, the issue of micro-intervals, because of the specific mathematical problems linked to the mathematics of small amounts, creates a situation where the otherwise very strong hold of arithmetic on musical theory is weakened. It is thus not surprising that the possibility of using geometrical concepts, and hence the issue of incommensurability, appears in such contexts.

Moreover, he who seeks to divide the tone into two equal parts is seeking to measure the diagonal by the side, which is impossible. ${ }^{12}$

The arithmetic allowing the manipulation of numbers, ratios, proportions, and various kinds of means necessary to study micro-intervals is essentially that presented in Boethius's De institutione musica. In characteristic fashion, Jean des Murs addressed this material several times, with further elaboration at different stages of his life. The Arbor Boecii and the De arithmetica are his first two treatments, while the first book of the Quadripartitum numerorum is, with certain passages in the second and third book, the core of his more mature reflection on the topic.

In the Quadripartitum numerorum several passages demonstrate Jean des Murs's continuing interest in music theory in various contexts. In the third book of his Quadripartitum numerorum, in chapter 6 , Jean des Murs addresses within a mathematical context the issue of the arithmetical impossibility of an exact semitone.

\footnotetext{
${ }^{10}$ This conclusion is mentioned for instance by Jean des Murs, De musica, I-conclusion 15, Meyer, 166-7.

${ }^{11}$ Jean des Murs, De musica, I-conclusion 14, Meyer, 162-64.

12 Jean des Murs, De musica, I-conclusion 6, ed. Meyer, '152: 'Rursus qui quaerit tonum per aequalia mediare, quaerit diametrum commensurare costae, quod est impossibile'. On an earlier mention of this comparison in a thirtheenth-century commentary on Boethius's De inst. Musica, see Rico, 'Music', 105.
} 
If in between two given numbers you wish to find a unique proportional mean, multiply one by the other and the root of the product, if it has a root, is the mean you are looking for. [...] And from there musicians understand that the tone cannot be halved in proportionally equal parts. ${ }^{13}$

The chapter from which this passage is extracted is actually a treatise on proportions. In the context of this chapter, proportions are understood in their full generality and examples are provided not only for proportions between integers but also for proportions between fractions. Among diverse properties and operations with proportions, the way to add and subtract them is addressed. It is interesting to note that on this specific topic the musical context is addressed as well and that the duality of the additive and multiplicative vocabulary is explicitly acknowledged. In this passage a fourth (i.e., a sesquitertia proportion as from 3 to 4 ) is subtracted from a fifth (i.e., a sesquialtera proportion as from 2 to 3 ) in order to form a tone (i.e., a sesquioctova proportion as from 8 to 9$).{ }^{14}$

And if a sesquitertia proportion is subtracted - [which is here] understood as 'divided'-from a sesquialtera proportion, a sequioctava proportion remains, and from experience you have no doubt that you know you have a tone. ${ }^{15}$

The explicit recognition of this dual vocabulary in a mathematical treatise on general proportions is important in the history of medieval proportion theory as it might have some echoes in Nicole Oresme's Algorismus proportionum, ${ }^{16}$ who also used an additive vocabulary for the composition of fractions. Another interesting instance showing that Jean des Murs had fully in mind his works in musical theory when writing the Quadripartitum numerorum connects directly to the passage of the De musica that opened this section: in chapter 20 of the first book Jean des Murs explains at length and in a general way the method used in the De musica to generate six continuous tones. ${ }^{17}$ These instances and others reflect Jean des Murs's attempts to connect the mathematics of music theory more tightly to the overall arithmetical body of knowledge of the fourteenth century. ${ }^{18}$

The Arbor Boecii and the De arithemtica show less explicit links to the musical context than the Quadripartitum numerorum. However, the reception of these works especially in musical manuscripts shows that medieval readers understood clearly the link with musical theory. ${ }^{19}$ The kind of mathematical work Jean des Murs carries out in these two earlier texts is very different

\footnotetext{
${ }^{13}$ Jean des Murs, Quadripartitum, III.6, ed. l'Huillier, 270: 'Si inter duos numeros datos unicum medium proportionale volueris invenire, unum duc in alium et producto radix, si radicem habeat, est medium quod tu queris $[\ldots]$ Et inde musici perceperunt tonum non posse per equalia proportionalia mediari.'

${ }^{14}$ To subtract a sesquitertia from a sesquialtera one has to divide their denomination (e.g. the quantities to which the proportions correspond). Using a fractional notation this can be expressed: $\frac{3}{2} / \frac{4}{3}=\frac{3}{2} * \frac{3}{4}=\frac{9}{8}$.

${ }^{15}$ Jean des Murs, Quadripartitum, III.6, ed. l'Huillier, 267: 'Sique proportio sesquitertia a proportione sesquialtera subtrahatur, intelligitur 'dividatur', sesquioctava proportio relinquetur, et jam cum experiencia non dubites te noscis habere tonum'.

${ }^{16}$ 1'Huillier, Le Quadripartitum, 28.

${ }^{17}$ Jean des Murs, Quadripartitum, I. 20, ed. l'Huillier, 171-3.

${ }^{18}$ Echoing a first attempt made in the Arbor Boecii, Jean des Murs here uses the vocabulary of musical proportion to classify fractions. See Jean des Murs, Quadripartitum, II.16, ed. l'Huillier, 204-5.

${ }^{19}$ For the diffusion of the Arbor Boecii in a musical context, see Christian Meyer, '... per venerandae memoriae magistrum Iohannem de Muris ...: la tradition parisienne de l'enseignement de Jean de Murs', in Gedenkschrift für Walter Pass, ed. Martin Czernin (Tutzing, 2002), 217-34. For the diffusion of the De arithmetica in a musical context, see Rico, 'Music', 67.
} 
from that proposed in the Quadripartitum numerorum. The De arithmetica and even more the Arbor Boecii constitute a contraction of the De institutione musica.

The contraction of Boethius's work is probably linked to the Parisian university context and shows some of the ways this arithmetic could be learned there. This type of intellectual work may explain also why, in contrast to the Quadripartitum numerorum, these two texts show less obvious links to the musical context. In another paper dedicated to the Arbor Boecii I have studied the kinds of contraction proposed by Jean des Murs in these texts and their mathematical effect. ${ }^{20}$ The results of this study show that Jean des Murs's contraction produced a systematisation of the content of the original. It also gave more strength to its main results. In sum, the contraction transforms and consolidates the main conceptual structure of Boethius's texts.

I was particularly interested in this earlier study in those sections of the Arbor Boecii that vary from one student copy to the next. In the present article, I should instead like to point to those sections of the Arbor Boecii that remain stable in those various copies and then form the core of the later fifteenth-century diffusion of the text in a musical context. While the most volatile part of the Arbor Boecii is probably its section on the classification of fractions, the most stable is without doubt the section presenting the vocabulary of De numero ad alium relato that transmits the basic terminology of musical theory relating to proportions. With respect to this particular section, it is noteworthy that the earliest known extant copy of the Arbor Boecii shows an interesting exponent notation for every ratio. ${ }^{21}$ For instance, the sesquialtera proportion as from 2 to 3 is noted as $2^{3}$. This notation might be another aspect of the reflection about the multiplicative and additive vocabulary of proportion that we have encountered above in the Quadripartitum numerorum. Moreover, this copy was produced by John of Saxony while he was studying with Jean de Lignières in the early 1320s and thus in a milieu where Jean des Murs was an important actor.

Micro-interval theory is on the edge. It is on the edge of sensible perception. It is on the edge of the arithmetically expressible and measurable. The issue of small amounts is intrinsically related to the exploration of these borders of the perceptible and the expressive powers of mathematics. Before leaving the musical context I would like to present a passage from the Notitia artis musicae where Jean des Murs expresses clearly how he understands the geography of this frontier.

Thus, because voice measured by time comprises the union of two forms, i.e., physical and mathematical, even though there is no end to the division into fractions according to one [of these forms], it is nevertheless necessary for it to end at some point due to the other division of the voice. For just as the nature of all permanent things dictates that there is a limit with regard to greatness and increase, so there [is a limit with regard to] smallness and decrease. For natural things prove that nature is limited with respect to the maximum and the minimum. The voice, however, is in itself a physical form that is accidentally joined to quantity. It must therefore have limits to its division into fractions. ${ }^{22}$

\footnotetext{
${ }^{20}$ Matthieu Husson, 'Les premiers témoins de l'Arbor Boecii de Jean de Murs: deux contextes distincts pour l'enseignement de l'arithmétique spéculative au XIVe siècle', in Mélanges en l'honneur de Danielle Jacquart (Geneva, forthcoming).

${ }^{21}$ MS Erfurt, Universitäts- und Forschungsbibliothek, Amplon. F. 377, fol. 35v.

${ }^{22}$ Jean des Murs, Notitia, II.2, Meyer, 78: 'Quoniam ergo vox tempore mensurata unionem duarum formarum, naturalis scilicet et mathematicae, comprehendit, licet quod ratione alterius fractio non cessaret, tamen propter aliam vocis divisionem necessarium est alicubi terminari. Nam sicut omnium natura constantium positus est
} 
This passage is not written within the context of micro-intervals theory. Rather, Jean des Murs posits the use of arithmetic not only in the study of intervals, but also in the study of rhythm and musical durations. In order to ground this very important step in the history of musical theory Jean des Murs relies on a sharp conception of the way mathematical and physical forms are articulated in a musical note. The first point of his thesis is that a musical note is essentially a natural or physical thing. It is associated by accident with a mathematical form. Thus when using mathematical reasoning on this accidental mathematical form associated with the physical note one has to make sure the manipulations made on the mathematical form can be matched in the physical form and do not contradict its nature. For instance, one can divide ad libitum a mathematical quantity but this is not the case, according to the doctrine of minima naturalia, ${ }^{23}$ for the physical quantity. This minimal limit of the musical note with respect to duration is the basis on which Jean des Murs builds his system of four nested duration degrees in the Notitia artis musicae. Thus not only did Jean des Murs have a sharp and clear conception of the relation between the mathematical and the physical when it came to the issue of small amounts, but very early in his intellectual career he was able to draw on this view to explore new ground and propose important innovations.

\section{Astronomical context}

Small amounts appear in the musical context as the difference between large but close quantities. The astronomical context offers many situations of this kind as it is often concerned with the evaluation and comparison of slow motions like that of the solar apogee or the eighth sphere. I here select an even more fundamental topic in order to show how small amounts may appear in astronomy: the length of the solar year. Jean des Murs opens his Expositio intentionis regis Alfonsii circa tabulas ejus with a short chapter titled De quantitate anni solis. ${ }^{24}$ In this part, he compares various lengths of the solar year. One of them is named the 'supposed length of the year'. It amounts to 365 and a quarter day and is the standard Julian year. In this chapter, he also compares various expressions of a length of a solar year he names 'true length of the year', which are found in sources that are attributed to Alfonso.

There is another length of the year which consists of the aforementioned 365 days, but with less than a quarter day-yet the size of this difference will be seen in what follows in accordance with the sense perceptions of the ancients and moderns - , and this [length] is named the 'true length of the year'. According to Alfonso it is $365 ; 14,3,9,59,20,7,30$ days and this is the [time] in which the Sun returns to its initial point, although it exceeds a complete revolution through the 12 signs by a few fourths, fifths, sixths etc., which you will know if you try to search for the motion that corresponds to the true length of the year given by Alfonso. For the sun's motion beyond 12 signs in this [time] is

\footnotetext{
terminus et ratio magnitudinis et augmenti sic parvitatis et diminuti. Demonstrant enim naturales, quod natura ad maxium et minimum terminatur. Vox autem est per se forma naturalis iuncta per accidens quantitati. Igitur oportet eam habere terminos fractionis.'

${ }^{23}$ Christoph Lüthy, John E Murdoch, and William R. Newman, eds., Late Medieval and Early Modern Corpuscular Matter Theories (Leiden, 2001)

${ }^{24}$ See Philipp Nothaft in this issue for further analysis of this passage in connection to Jean des Murs's Canones of 1339 .
} 
$0.0 ; 0,0,0,2,13,45,34,27,39,42,49,59,32,7$. The Sun thus moves beyond by this value during the true year, but this is very small and imperceptible, because it does not sum up to a minute after 90,000 years. Beyond the supposed length of the year, by contrast, the Sun moves by a perceptible length that is close to one day in 134 years. ${ }^{25}$

This passage introduces four different numerical values and prepares the computations and verifications that will be made later in the chapter. In this respect, the De quantite anni soli follows the same reasoning structure that appeared in the passage from the De musica that opened this paper. The first numerical value is the length of the solar year according to Alfonso. The second is an evaluation of the motion of the Sun during the Alfonsine solar year given first. This evaluation must rely on another piece of numerical information, in all likelihood a daily mean motion of the Sun, not provided at this initial point of the text. The year length multiplied by a mean daily motion of the Sun will produce the position of the Sun after one year. ${ }^{26}$ Then the accuracy of the Alfonsine estimation of the length of the solar year, or, to be more precise, the coherence of its expression as a year length and as a daily mean motion, is measured with the third numerical information: it takes more than 90,000 years for this amount to reach a minute of arc. ${ }^{27} \mathrm{It}$ is thus not perceptible. This level of accuracy is compared to that of the supposed year length, which produces a shift of almost a degree in the Sun's longitude, and thus of one day in the calendar every 134 years. The small amount here is the second numerical value of the passage. It is clearly acknowledged as such and even as beyond the perceptible by Jean des Murs. In a way very similar to what was the case in the musical context this small amount is produced by the comparison of two large quantities that are subtracted one from the other. The first quantity is the motion of the Sun during an Alfonsine true solar year. The second quantity is a full circle. In the text following this passage, these quantities and other related ones are combined in various computations that tie them together and make it possible to test their mutual coherence. ${ }^{28}$ These computations are more complex than those encountered in the musical context, especially because more than two close and large quantities need to be compared. However, beyond some technical complexities, they rely on the same general rationale.

The numbers used to express astronomical quantities are very different from those encountered in musical theory. First, two types of quantities are used: arcs and durations. Second, durations are expressed with more than one system of measuring units. Third,

\footnotetext{
${ }^{25}$ Poulle, 'Jean de Murs', 250-1: 'Est et alia anni quantitas que est ex diebus predictis 365 sed minus quarta diei, sed quantum minus videbitur in processu, sicut sensibiliter ab antiquis et novis est expertum, et vocetur ista "quantitas anni vera", que secundum Alfonsium talis est: $365 ; 14.33 .9 .59 .20 .7 .30 \mathrm{~d}$ et in ista redit sol de primo puncto ad ipsum, transiens tamen ultra revolutionem 12 signorum per aliqua quarta, quinta, sexta, etc. quod scies si vis querere motum solis in vera quantitate anni ab Alfonsio data; nam motus solis in ea ultra revolutionemn 12 signorum talis est 0.0;0.0.0.2.13.45.34.27.39.42.49.59.32.7. Transit ergo sol tantum secundum veram anni quantitatem, sed istud est minutum et insensibile quia ad minuta non pervenit donec perveniatur ad annos solares 90000. Sed ultra quantitatem anni suppositam transit sol per sensibilem quantitatem sicut fere per unum diem in 134 annis'.

${ }^{26}$ The result given by Jean des Murs does not match modern recomputation. See Philipp Nothaft's contribution to this issue quoting Poulle, 'Jean de Murs', 251.

${ }^{27}$ This evaluation is correct although imprecise. According to Poulle, 'Jean de Murs', 251, a shift of one minute will occur only after 104,400 years.

${ }^{28}$ See Matthieu Husson, 'L'astronomie alphonsine dans l'Expositio intentionis regis alfonsii circa tabulas ejus de Jean de Murs', Archives d'histoire doctrinale et littéraire du Moyen Age 78 (2011), 229-45, esp. 235-38.
} 
astronomers use sexagesimal fractions and not integers. However, in order to express small differences between very large quantities the numbers used by astronomers, just as the numbers used in micro-interval theory, must have many digits. The organisation of the information in the number is not the same and thus the meaning of the digits, the way to compute with them, is different, yet in order to manipulate tiny amounts, both music and astronomy need high precision numbers. Another point of comparison of the role of small amounts in both the musical and astronomical context is the link Jean des Murs builds with the issue of incommensurability. The first clearly attested mention of this issue in relation to astronomy is found in the last book of the Quadripartitum numerorum in the context of a general treatise on motion and the pursuit problem.

If two circles above the same centre are incommensurable, such as the diagonal and the side, and two moving things begin to move along these circles from a common point, they will, if the revolutions continue forever, never come together in a numbered part in all eternity, because if the opposite were assumed, they would be commensurable one to the other. ${ }^{29}$

This chapter concerns a conjunction problem and relates it to a question of measurement: if two moving things come in conjunction after starting from the same point, it means that one can measure one motion by the other, or that they share a common measure. In the same way, the question of the length of the year is a question of measurement, or a problem of conjunction with a fixed point. Thus, as was the case in the musical contexts, mathematical work with small amounts is on the edge of the mathematically expressible and connected to the issue of incommensurability. It is also on the edge of the perceptible. The passage from the Expositio mentioned clearly that one amount actually was beyond the perceptible and went as far as proposing a measure of this property. In fact, in the same treatise of the Quadripartitum numerorum Jean des Murs returns to the topic of incommensurability and addresses the consequence it might have for the astronomer's work. ${ }^{30}$

It is nevertheless enough for the astronomer that he predicts conjunctions of planets and stars so that the senses are not capable of showing the opposite. For the learned person does good to quiet down as long as the intellect satisfies the senses. Because he who searches beyond is not in the realm of the sensible. ${ }^{31}$

In other words, incommensurability and small quantities that lie beyond the perceptible are important mathematically, but not more: they are a problem for the mathematician, not for the astronomer concerned with the task of providing a cause for the phenomenon: beyond the perceptible, there are no phenomena to explain. This position is close to that tacitly expressed in musical theory, where Jean des Murs makes no efforts to analyse any further than the comma,

\footnotetext{
${ }^{29}$ Jean des Murs, Quadripartitum, IV-1.14, ed. l'Huillier, 490: 'Si autem sint duo circuli incommensurabiles ut sunt dyameter et costa super idem centrum, et a puncto communi inciperent duo mobilia illos duos circulos pertransire, nunquam in parte numerali in eternum conjungerentur, factis revolutionibus sempiternis, quia posito contrario, essent ad invicem commensurabiles'.

${ }^{30}$ On the scale of a single work this is again a manifestation of Jean des Murs's habit to return to the same topics in order to elaborate them further.

${ }^{31}$ Jean des Murs, Quadripartitum, IV-1.24, l'Huillier, 502 'Sufficit tamen astrologo quod conjunctiones planetarum et siderum sic predicat quod sensus ostendere contrarium non valent. Est enim bene doctrinati requiescere, dum intellectus sensui satisfacit. Quod qui querit ultra non est de gremio sensatorum.'
} 
precisely because it is the tiniest perceptible musical interval. However, this does not mean that Jean des Murs thought observation was not an important part of the astronomer's endeavour. Jean des Murs left many records of astronomical observations. Among those, the one reported in the Expositio, maybe because of an enthusiasm of the young age, is probably the most expressive. Here are the first sentences of this report where Jean des Murs takes a path similar to that of Guillaume of Saint Cloud and reproduces one of his earlier attempts to measure the length of the solar year.

And I, the abovementioned Jean, affected by a great desire to recognise the truth of this by the senses, having on my heart to confer and understand all these things, erected on a meridian line a suitable instrument 15 feet in diameter that contains the sixth part of a quadrant, which is called kardaga. It was on a stone immobile and as straight as possible. And, with the shadow of the Sun shining noticeably on 13 March with the letter B in the completed year 1318 [as counted] from January, I found the Sun's altitude on the meridian of the city of Evreux, which is at a small distance from Paris to the west, at $41 ; 26,40^{\circ} .32$

The description of the observation including several subsequent computations continues in the Expositio for several lines. In sharp contrast to the situation in musical theory, where the De institutione arithmetica is without doubt a corner stone of medieval mathematics, the mathematics allowing to express, measure, compute, and construct reasoning with astronomical quantities were less firmly established when Jean des Murs began his intellectual career in the early fourteenth century. ${ }^{33}$ By the end of his career, early in the second half of the fourteenth century, this situation was transformed partly because of Jean des Murs's own efforts. Jean de Lignières's Algorismus minutiarum ${ }^{34}$ and Jean des Murs's canons to the Tabula tabularum are two important arithmetical works developing the elementary aspects of computing with sexagesimal fractions. In different ways they took out of astronomical canons a scattered arithmetical material and organised it in an autonomous way. The Algorismus minutiarum systematically compares computations with usual fractions and computations with sexagesimal fractions and has a very factual and practical tone. The Tabula tabularum is a more creative or exploratory work. Starting from a sexagesimal multiplication table Jean de Murs's aim is to develop a complete algorism of sexagesimal numbers including the computation of square and square roots. This enterprise is mathematically not trivial and actually not fully successful. However, it drives Jean des Murs toward several fruitful reflections concerning the nature of arithmetical operations, their relation, or the nature of numbers. With regard to numbers themselves, Jean des Murs relies on some sort of a floating numbers system (i.e., no order of magnitude is specified) in order to design procedures that can apply to any sexagesimal number from a single multiplication table. He also assumes that any quantity can be expressed sexagesimally and builds bridges between sexagesimal arithmetic and that of fractions and integers of a deeper nature than those elaborated by Jean de

\footnotetext{
${ }^{32}$ Poulle, 'Jean de Murs', 266-7: 'Et ego prefatus Johannes multo affectu desiderans veritatem hujus sensibiliter agnoscere, mihi corde omnia ista conferens et comprehendens, instrumentum ad hoc congruum 15 pedum in semidyametro continens $6^{\mathrm{am}}$ partem quadrantis arcuatam, quod kardaga nominatur, elevavi in linea meridionali super lapidem immobilem rectissime quantum possibile fuit et, umbra solis notabiliter radiante, anno Domini 1318 [perfecto] a januario $13^{\text {a }}$ die martii super litteram B, inveni altitudinem solis meridianam in dicta civitate Ebroicensi que ad modicum distat a Parisius ab occidente $41 ; 26.40^{\circ}$.

${ }^{33}$ Ptolemy's Almagest does not address the arithmetical aspects of astronomical practices.

${ }^{34}$ H. L. L. Busard, Het rekenen met breuken in de middleleeuwen, in het bijzonder bii Johannes de Lineriis (Brussels, 1968).
} 
Lignères in the Algorismus minutiarum. Therefore, a well-formed sexagesimal algorism could be useful well beyond astronomy. In trying to pursue these ambitious aims, Jean des Murs uses several kinds of mathematical prose: procedural texts, auto-commentaries on those procedures, and Euclidean axiomatic style. The mathematical work proposed in the canons of the Tabula tabularum lies in the interaction between these three types of mathematical prose. ${ }^{35}$ However, many significant ideas are expressed in the Euclidean passages. There are two such sequences in the canons. The first grounds and prepares the multiplication procedures and their comments. The second grounds and prepares the division procedures and their comments.

Common notions: every whole is greater than its part. If a number is called 'one' it will be the smallest of all numbers. Every unit can always be considered divisible. Any [quantity] multiplied by one reproduces itself. Any [quantity] multiplied by less than one produces less than itself. Unit, integer smaller than one, and fraction correspond to each other. Every multiplication is a kind of addition. Every division is a kind of subtraction. ${ }^{36}$

Jean's mathematical treatment of the notion of unit, here founded on the notion of whole and parts, is remarkable. The first point is to affirm that a unit is actually divisible. This implies that a unit is a whole that can be divided into parts. These parts can then be numbered and form new kinds of integers based on a smaller unit. Thus, the possibility of the strange expression integrum minus uno, which corresponds to fractions. This system of nested units, at the base of sexagesimal arithmetic, is there clearly expressed and firmly, albeit briefly, philosophically grounded. Another aspect of this passage is the work on multiplication and division as operation. They are related respectively to particular forms of addition and subtraction. This theme is further developed in the Tabula tabularum and nicely echoes some of the reflections encountered in the musical context about the dual additive and multiplicative vocabulary in the manipulation of ratios. Maybe because of the minor status of sexagesimal arithmetic with respect to that of integer and proportion, the Quadripartitum numerorum does not address directly the question of sexagesimal fractions. However, the idea that sexagesimal numbers can be used to express any quantity is present in the work. For instance, when computing square roots of integers Jean des Murs uses the opportunity to express the result of this computation sexagesimally. Interestingly, this also drives him to explore the possibility of using decimal fractions and even fractions formed with an arbitrary factor. ${ }^{37}$ Another development of arguments from the Tabula tabularum in Jean des Murs's treatment of fractions in the Quadripartitum numerorum is the use of Euclidean axiomatic parts in order to define fractions or introduce different kinds of operation based on them. The philosophical grounding of fractions in the doctrine of the whole and the parts is, for instance, also at the base of the definition found in the Quadripartitum numerorum. ${ }^{38}$ The possibility of dividing any level of unit into smaller fractions and thus of expressing mathematically small

\footnotetext{
${ }^{35}$ Matthieu Husson, 'La Tabula tabularum de Jean de Murs et les modèles de l'arithmétique médiévale', Cahiers de recherches médiévales et humanistes 27 (2014), 97-122.

${ }^{36}$ MS Paris, Bibliothèque nationale de France, lat. 7401, p. 115 'Dignitates: omne totum est maius sua parte. Si unum numerus appelletur erit minimus numerorum. Omne unum in semper divisibilia reputatur. Quidquam per unum multiplicatur se ipsum prodicit. Quidquam per minus uno minus se ipso procreat. Unum et integrum minus uno et fraccio convertuntur. Omni multiplicacione aliquatum addicio Omni divisione aliqua subtraccio correspondet.'

${ }^{37}$ Jean des Murs, Quadripartitum, II.22, ed. l'Huillier, 237.

${ }^{38}$ Jean des Murs, Quadripartitum, II.15, ed. l'Huillier, 201-2.
} 
amounts must also meet the frontier of the perceptible and challenge the relation between mathematical and physical forms. Jean des Murs presents his thesis on this question in the Euclidean axiomatical part of the Tabula tabularum.

Suppositions: a degree is called integer in analogy to units. Minutes are named the immediate division of an integer as if less than a unit. The second, the third, the fourth are called fractions of fractions and continue as far as the divider wishes and the nature of the thing allows it to be cut up..$^{39}$

The position expressed in the Tabula tabularum with respect to the limit of the applicability of infinite mathematical division when it comes to actual natural quantity is strictly identical to that proposed in the Notitia artis musicae. The way Jean des Murs conceives of the relation between mathematics and natural philosophy is coherent across the quadrivium. The permanence of this position is clear as it is also expressed in the Quadripartitum numerorum.

For the mathematician considers his proportions absolutely. And just as he would say that two cubes are the double from one, so he would say that two skies are in double proportion to one, and that the diameter of the sky is the triple with a seventh to the circumference, or that the square of the diameter is greater than its orb, if this is what his work requires. But the natural philosopher, accepting thing as they are, not as they can be, says that once one has arrived at the minimum or maximum, there will be no going further. For the mathematician there is neither minimum, unless by hypotheses, nor maximum, nor first or last, unless there is found for us a first line or point. By contrast, just as it is licit to the mathematician to double or triple any given quantity, so it is [licit for him] to halve it, such that he proceeds unto infinity in either direction. ${ }^{40}$

For Jean des Murs the relation of mathematical and physical forms is closely related to their divergent relation to small (and large) amounts. In the musical context, Jean des Murs relied on this position to ground philosophically the very possibility of using arithmetic in musica practica. In a similar way when discussing the issues of motions in the Quadripartitum numerorum, not only does he make use of his competence as an astronomer, but he claims that the calculatores, because they failed to acknowledge the true relation of mathematical and physical forms in the scientiae mediae, are driven to false reasoning and conclusions.

Conversely, the following would hold true: As time increases, a force decreases according to the nature of the mathematical proportion. But be careful that nothing wrong is inferred, you who examines a special matter. Because if a force moves at the limit of its power some movable in a given time and the time is doubled, it does not follow that the force divided by half will move the same

\footnotetext{
${ }^{39}$ MS Paris, Bibliothèque nationale de France, lat. 7401, p. 115: 'Supposiciones: Gradus dicitur integrus simile unitati. Minutum dicitur integri immediata fraccio quasi minus uno. Secunda, tercia, quarta, dicuntur fraccionis fracciones procedendo quamdiu libuerit divisori et natura rei potest permittere seccionem.'

${ }^{40}$ Jean des Murs, Quadripartitum, IV-1.11bis, ed. l'Huillier, 485: 'Mathematicus enim suas proportiones considerat absolute. Et sicut diceret quod duo cubici sunt duplum unius, ita diceret quod duo celi sunt in dupla proportione ad unum, et dyameter celi triplicata cum sui septima reddit periferiam, aut quadratum dyametri celi superat orbem suum cum hoc exigit opus suum. Sed physicus res ut sunt, non ut esse possunt recipiens ait de vento ad minimum et maximum non fore ulterius procedendum. Apud mathematicum, nichil minimum, nisi ex suppositione, nichil etiam maximum neque primum neque ultimum nisi nobis invenitur linea prima atque punctum. Sicut autem licitum est mathematico omnem datam duplare aut triplare quantitatem sic etiam quamlibet mediare utraque via in infinitum procedendo hec de hiis.'
} 
mover in some duration of time, for it might be no [time] at all. Or if this were the case, any force no matter how small could move the greatest movable, which is false. For although it is true that what a small force can do, a larger force can do in less time, it does not follow conversely that what a larger [force] can do, a smaller one can do in more time, for the reason already given. ${ }^{41}$

\section{Conclusion}

In manipulating small amounts, usually generated by the comparison of large and close quantities, Jean des Murs needed high precision numbers with many digits. In the musical context, these high precision numbers are generated by successive multiplications, according to rules ultimately presented in the De institutione arithmetica. In the astronomical context these high precision number are generated through successive divisions. Thus music and astronomy explore the mathematical possibilities proposed by the two main medieval definitions of numbers ${ }^{42}$ in order to address the same fundamental issue. Among the many contrasts that appeared between the musical and astronomical context in the study of small amounts I want to stress also the fact that in astronomy the mathematical theory allowing to manipulate the specific type of numbers used was much less developed and established than it was in music where medieval actors could rely on Boethius's works. Jean des Murs, with other astronomers in his milieu such as Jean de Lignières, made modest but significant steps in shaping this arithmetic. The exploration of the use of sexagesimal (and decimal) fractions by Jean des Murs in the Quadripartitum numerorum in the calculation of square roots is a remarkable example. However, the fact that the issue of small amounts was recognised as one general question across quadrivial disciplines by Jean des Murs was also made clear, I hope, by the connection made several times with the issue of incommensurability and by the repeated thesis that Jean des Murs holds regarding the relation between the mathematical and the physical with respect to small amounts, the possibility of division, and the limits of sense perception. This paper also aimed at showing that relying on this thesis Jean des Murs felt on secure ground to explore new possibilities in music and to take a 'conservative' position in the emerging debates about the mathematics of motion. The link of the issue of small amounts with the mathematical problem of incommensurability also opens new paths of research into the mathematical works of Jean des Murs. The early mathematical works prepare many aspects that are then more developed in the more mature encyclopaedic works Quadripartitum numerorum and De arte mensurandi. However, algebraic methods do not appear in the early works, whereas they are central to the two later ones. A study of the interaction of these algebraic methods with the question of incommensurability and the issue of small amounts would probably be rewarding.

This study has also shown some interesting working habits of Jean des Murs. For instance, it illustrated his persistence in the exploration of some issues to which he returned several times in different works. The theme of fractions, sexagesimal or not, their possible links

\footnotetext{
${ }^{41}$ Jean des Murs, Quadripartitum, IV-1.11bis, ed. l'Huillier, 486: 'Ita teneret econverso. Tempore aucto, minuitur virtus quantum est ex natura mathematice proportionis. Sed cave ne inde incoveniens inferatur, tu qui consideras materiam specialem. Nam si virtus movet ad ultimum potentie per datum tempus aliquod mobile et tempus in duplo augeatur, non sequitur ergo virtus in subduplo diminuto idem mobile movebit per aliquod tempus, nam forte per nullum. Aut si sit quelibet virtus quantumlibet parva, moveret maximum mobile, quod est falsum, quoniam licet quod potest minor virtus potest major in minori tempore, non tamen convertitur quod potest major potest minor in majori tempore propter causam dictam.'

${ }^{42}$ Numbers are either considered as generated from a collection of units or as resulting from the ongoing division of a continuous quantity.
} 
to proportions and ratio, and their use in various type of computations was encountered in the Tabula tabularum, the Arbor Boecii, and the Quadripartitum numerorum. The reflection on the relations of the different fundamental arithmetical operations, across the type of quantities or proportions to which they might be applied, is also a deep theme that was encountered in the arithmetical, musical and astronomical context. This theme produced in particular interesting correspondences between addition and multiplication on one side, subtraction and division, on the other. One other interesting element of Jean des Murs's working habits that appeared in this study concerns the kind of relation he built with his sources. In this respect, the treatment he gave to the De institutione arithmetica is exemplary, with a contraction and consolidation phase followed by a phase where the content is connected to different mathematical fields. The kind of work proposed in the Tabula tabularum with the combination of several types of mathematical prose to explore new grounds is also very interesting, especially as it display in a small text a method that Jean des Murs will use later more extensively in the Quadripartitum numerorum and the De arte mensurandi. Finally, the deep and numerous relations between Jean des Murs's works in arithmetic (and geometry) and those in music theory and astronomy that appeared in this article are a clear incentive to follow this approach more systematically and study Jean des Murs's quadrivium from the perspective of his mathematical works. 